\title{
Election campaign tools in Hungarian humour magazines in the second half of the 19th century
}

\author{
Ágnes Tamás \\ University of Szeged \\ tagnes83@yahoo.com
}

\begin{abstract}
In my research paper I examine the first two election campaigns in Hungary following the Austro-Hungarian Compromise (1867). In particular, I analyse the ways the campaigns employed tools of humour in popular press products of the time, such as caricatures and texts in humour magazines (Ludas Matyi ['Mattie the Goose-Boy'], Az Üstökös ['The Comet'], Borsszem Jankó ['Johnny Peppercorn']), which were considered effective political weapons by contemporaries. After a history-oriented introduction devoted to illustrating the muchdebated content of the Compromise, the election system and the historical significance of the analysed papers, I categorize caricatures and the humorous or satirical texts related to the election of parliamentarians along the lines of the following aspects: (1) attacks against specific people, (2) standing up against the principles and political symbols of the opponent, (3) listing well-known, everyday anti-theses, (4) standing up against the press of the opponent, (5) judgment of the role of the Jewish, (6) war metaphors, (7) critique of the campaign methods of the opponent. My goal is to reveal what tools were used to ridicule political opponents, how parties were described to (potential) voters, how the parties tried to promote voting and convince people of their points of view. The analysed texts clearly depict the division of the Hungarian society (either supporting or rejecting the Compromise), and also document that the political tones became coarser and coarser, even in this humorous genre. During campaigns, the topic of elections took over the humour magazines, which serves as evidence for the intensity of public interest.
\end{abstract}

Keywords: election campaign methods, Hungarian humour magazines, Austro-Hungarian Compromise.

\section{Introduction}

When it comes to elections, we cannot disregard even today the types of tools applied and the number of voters to be convinced and encouraged by a party. As a result, ever since the very first election and press products were available, media affiliated with the parties have attempted to influence voters' opinions and persuade their own voters to take part in the ball. The aim of my research is to examine in what ways popular press products of the mid-19th 
century, namely political humour magazines belonging to parties, tried to influence readers' viewpoints, in what register they spoke to the voters, what methods they applied to ridicule opponents, and how they introduced representative candidates. I have chosen this source because contemporaries considered humour and sarcasm as strong political weapons, emphasising that a good caricature or a text in a humour magazine can be more effective than a leading article. According to a lexicon published at the end of the 19th century, for example, caricatures "play a huge role in political party fights" (Pallas 1897: 284). The elections became the primary topic of humour papers beginning at the period before the elections, therefore, contemporaries attributed an influential role to these press products.

The selected era under scrutiny is not accidental either: I analyse the first two elections (1869, 1872) following the Austro-Hungarian Compromise, leading to the creation of the Austro-Hungarian Monarchy. They were rather vehement, tense and corrupt political fights. Before the 1874 amendment of the election laws and the transformation of precincts (1877), the opposition still had the mathematical possibility of winning. The birth of the Monarchy was not supported by most of the Hungarian nation; on the contrary, a notable part of the society disagreed with certain points of the Compromise. It was a kind of regime change, as opposed to the Central-Eastern-European processes at the end of the 1980s and the beginning of the 1990s, for which the majority of Hungarians did not stand up. It was the legitimisation of a new system which was at stake, and not whether the governing party remained in power or failed, so the opinions expressed in humour magazines about the Compromise and the elections were strongly interconnected during the years investigated in this paper.

Firstly, those points of the Austro-Hungarian Compromise will be presented which were debated by Hungarian contemporaries, since familiarity with them is inevitable for the understanding of the caricatures and texts of the magazines. As a follow-up, the process of Hungarian elections will be described in the middle of the 19th century as the peculiarities of the political system have always affected election campaigns and campaign tools. The sources of the analysis and the significance of humour magazines at the time will also be characterised, and lastly, the campaign tools of the papers will be examined. My analysis will be illustrated with contemporary texts and caricatures. I will also take a close look at the not necessarily humorous texts and pictures of the humour magazines from a historical point of view.

\section{The contents of the Austro-Hungarian Compromise and the opinion of contemporaries}

The Austro-Hungarian Compromise was the result of a long process: the liberal Hungarian political elite, after the failures of previous attempts in the $1860 \mathrm{~s}$, took part in negotiations with the monarch, Franz Joseph I, trying to settle the problems between Austria and Hungary. These negotiations speeded up when Prussia defeated the Austrian Empire (1866) and it became obvious that a united Germany would be formed under the leadership of Prussia instead of that of Austria. The law which was created as a result of this process in the spring of 1867 is what we know as the Austro-Hungarian Compromise. The contents of the Compromise divided the political parties and the nation. Thus, the Hungarian party system did not follow the pattern of the classic Western-European one as demarcation came about based on the acceptance or rejection of the Compromise. The most controversial part of it is Article 12 of 1867 about the handling of Austrian-Hungarian common affairs. The elaboration of the law was unquestionably connected to the name of Ferenc Deák (18031876); and the liberal party most supportive of the Compromise was called Deák Party. The article states that foreign and military affairs and financial affairs funding the former two are 
common affairs, to be handled by common ministers. The army is joint, and its leader is the monarch. They also realized that the two halves of the Empire were connected by several other affairs of common interest without which the operation of a united empire is hardly feasible (e.g. currency, trade contracts, loans). Hungary also took upon itself part of Austria's debt. The handling of common affairs was carefully organised: elected bodies and delegations were formed whose main duty was to draw up a common budget. The amount to be covered by each country was re-negotiated every ten years by the Austrian and Hungarian political leaders. In 1867 they agreed that Hungary should provide 30 per cent of the common expenses. This 30:70 per cent rate was called quota.

Contemporaries criticised several points of the Compromise, the extreme left rejected it altogether. This group promoted the independence of Hungary, they wanted the two countries to be only connected by the monarch; in other words, they believed in a personal union. Some of them, though, supported complete independence in accordance with Lajos Kossuth (18021894). ${ }^{1}$ In their press products they unmercifully attacked the Compromise and Deák himself. A more moderate criticism was formulated by the Centre-Left Party which accepted the Compromise but demanded amendments. They did not agree with the method of handling the common affairs and did not accept the institution of delegates either. Following the enactment of the Compromise, anti-compromise feelings were common, which was characteristic not only of Hungary. Some social layers, minorities, and political groups expressed their dissatisfaction in the Western part of the Empire as well when the emperor came to an agreement with the Hungarian political elite. The parties had to organize the first elections and campaigns in such political climate, knowing that the monarch would not appoint a prime minister from the opposition. ${ }^{2}$

\section{The analysed humour magazines and their readers}

According to contemporary definitions, which coincide with the findings of the literature, one of the most important criteria of a party, which was of a much looser structure compared to that of the 21 st century, is that it should have its own press products, hold regular meetings (at least before the election), and have its own seat where the representatives can gather (as cited by Toth 1973: 35). The press of the party played an essential role in party structure even outside the election periods, which, according to Toth, with its feisty style and political fights, had an influential impact on the formation of Hungarian politics (1973: 71). Hungary's party press included not only daily political newspapers but humour magazines as well, strongly affiliated with political parties. Hungary was full of short-lived humour papers in 1848, after 1848 censorship made publishing newspapers more difficult. Freedom of the press was reset with the Compromise of 1867 and political humour magazines could be published in large numbers.

By the time of the 1869 elections, each party had their own humour magazine. The earliest example of such papers was edited by novelist Mór Jókai (1825-1904), published starting from 1858. Jókai shared the views of centre-left politics, and propagated their ideas in his magazine. After the enactment of the law about common affairs in March 1867, a humour magazine titled the Ludas Matyi was published in April 1867, edited by Károly Mészáros, whose purpose was specifically to be a humour magazine that attacks the Compromise. In the end of 1867 the government had decided, having witnessed the success of press of the opposition, that it was necessary to start publishing a humour paper for the governing party. The first issue of the Borsszem Jankó was published on 5 January 1868 and the idea came from the prime minister himself, Count Gyula Andrássy (1823-1890). He 
trusted Adolf Ágai with editing the paper, who was then the well-known editor of a humorous magazine (Bolond Miska). ${ }^{3}$

Besides their popularity, the source value of these magazines was amplified by the drawings they contained, a technique which did not necessarily belong to the era as images were not characteristic of press products, yet, their significance was obvious because even those people who could not read could take a look and understand them. Humorous-sarcastic content and a well-made caricature were often rather capturing and thought-provoking. Even more so, as modern semiotics and communication theories claim, images interpreted together with texts belonging to them can carry surplus meaning, something I found several times in the analysed corpus (see e.g. Sanz 2013: 10-11).

On the other hand, it is also important to emphasise that at that time readers played an active role in the editing process of humour magazines: they sent text, anecdotes, and their own humorous poems or caricatures to the editors, so it was not only the permanent employees' texts that we could read. Humour magazines did not only make society face itself but also provided the reflections of the readers' opinions as well (about comic papers see Tamás 2010: 274-275 and Tamás 2014: 59-96).

\section{The election system and factors influencing voters' attitudes}

The aim of every political party and election campaign is to maximise the number of its supporters. A vital criterion of a successful election campaign, on the side of the candidates, is to be familiar with the features of the election system as well as the potential ways of motivating the voters (Strömbäck \& Kiousis 2014: 111). Even though this phenomenon has various names, modern literature on election campaigns attributes the same traits to the early period of the campaigns (Strömbäck \& Kiousis 2014: 117; Plasser 2009: 26). The era analysed in this study belongs to this early period both in Hungary and in Western-Europe. Its main characteristic is that parties of that time had rather loose structures. Campaign activities were mostly local, and did not last long. Communication was mostly performed face to face: voters went to the events of politicians, they met them or their canvassers live. In those election campaigns candidates and parties could only rely on a single type of media: local and national printed press. Richard M. Perloff points out when analysing early American election campaigns that party press over there did not shy away from anything: it operated with sharp personal remarks about the candidates of the opposition, which might not fit into the frame of political correctness today (cited by Mihályffy 2009: 66-67). The traits of the coarse style of the press can be identified in this corpus as well. Voters of the time were characterised by a high level of party loyalty, often infiltrated with family traditions (which some authors compare to religious commitment and faith), so the mobilisation of the voters was the main task of the parties and the press, not as much, only in later periods, as the persuasion of uncertain voters. As we will see, most of the features introduced based on international literature are applicable to both Hungarian election campaigns under analysis.

Before the analysis of humour magazines, an overview of the system of elections in Hungary will be provided, which had a great impact on campaign tools and the results of the campaigns. At the time it was customary to vote openly on individual candidates. The ones whose financial background made it possible could run for being a representative in more than one precinct in order to ensure a place for themselves. Literacy was not necessary for voting since voting happened either orally or the voters put long sticks into the boxes. 6.6 per cent of the whole population had the right to vote in 1869 and this number was almost the same in 1872 (6.5 per cent). Voters were motivated to talk about their opinions, so candidates could mobilise them since in $1869,73.37$ per cent of those who had right did cast their votes 
(Boros \& Szabó 1999: 136-145). In addition, one also has to take into consideration those who could influence the voters but could not vote and yet participated in election events: men without the right to vote and, in some cases, women.

Voting happened not only in one day but even throughout weeks (9-13 March 1869; 12 June-9 July 1872). There was a venue in each precinct which could be considered a way of manipulation as many of those who had the right to vote could only avail themselves of it after long journeys. Even the contemporaries took notice of the corruption and the possibilities for cheating which were given because of the system itself. We know numerous ways of corruption and incitement: a few forints of allowance, transportation to the voting venue, or the widespread events of feasts with eating and drinking (for further information on the elections in English see Gerö 1997: 9-11). Therefore, campaigns cost the candidates a lot of money. Various factors influenced the attitudes of voters: ethnic and religious ties, geographical environment, position in the old feudal society, family relations, and social status (Gerhard 2010: 182-184).

The demonstrated features, the corruption and manipulation were not unique to Hungary at the time. We know it from Western-European analyses that the above listed traits belonged just as much to the election system and campaigns of Great-Britain until the right to vote was given to a wider range of people. A large group of people cannot be mobilised or bribed in the same way as one by one (Mihályffy 2009: 59-60). The Hungarian government at the time of the dualism did not expand; what is more, it narrowed down the right to vote: they were afraid of the rise of anti-Compromise forces and the popularity of minority representatives.

\section{Elections and the chosen election campaign tools in humour magazines}

Since elections were held every three years, contemporaries were preparing to hold an election for parliamentary representatives in 1868 after the one in 1865 . In line with the expectations, in an intensified political climate, humour magazines featured campaigns from the autumn of 1868. Moreover, it was not unusual to find them mentioning the "approaching" elections as early as the second half of 1867 . They encouraged the voters to take part and started a negative campaign, a characteristic of the era, whose primary aim was to ridicule the opponent. Negative campaigns, as well as negative caricatures of a candidate are often used nowadays, too. However, according to results of different researches, satire is not equally effective in all groups (O'Connor 2017: 204, 216-217), and neither is the election campaigns in the comic papers.

It is agreed upon by experts of election campaign analysis that prior to the period of modern election campaigns, the short, ad hoc campaigns were the most popular ones. In this regard, the 1869 election is an exception because the preparations for the elections, even less systematic, started early, at the end of 1867 and the beginning of 1868 . Anticipation is also demonstrated by the fact that short, humorous stories were published about previous elections: one can read about a doctor who even takes his patient with him to vote in his horse carriage, and about great feasts. At the beginning of 1868 the editor of the Ludas Matyi is still hopeful: he is convinced that the left would win the elections. This idea is expressed through a poem which praises Kossuth and reminds readers of the Revolution of 1848 even with its title (To the Year 1848), implying that this election on the 20th anniversary of the Revolution would be of great significance (LM, 19 January 1868).

Anticipation was less intense before the following 1872 elections. There was barely anything written about the elections in humour papers in 1871; we can only find one or two mentions of alcohol-fuelled canvassing trips. In one of them, however, the author said that preparatory works for the upcoming elections should have started, although we could not see 
any trace of these preparations in the papers. What is more, in 1872 the magazine of the extreme left accused the political elite of not being active enough in terms of canvassing and campaigning, unlike in 1869 (LM, 4 February 1872). The difficult position of the opposition was pointed out by Jókai's magazine in 1871: "if it wants to win the elections, it should just give up its standpoint and join the right" (Ü, 23 September 1871). So even some MPs sensed that it would be difficult to win with an anti-Compromise programme in such a political climate. The campaign in humour magazines only started in March, resulting in a much shorter campaign period compared to the one in 1869, but this fits the period's features more.

I will examine campaign tools used in the images and texts of humour magazines from the perspectives of the following aspects:

(1) attacks against specific people

(2) standing up against the principles and political symbols of the opponent

(3) listing well-known anti-theses

(4) standing up against the press of the opponent

(5) judgment of the role of the Jewish

(6) war metaphors

(7) critique of the campaign methods of the opponent

The campaign tools are predominantly similar in the time periods under scrutiny, so I discuss them simultaneously. If differences can be found or tones vary in the data taken from the two campaigns, I compare them and conclude what humorous-sarcastic or satirical method, theme or symbol was more characteristic of each campaign.

\subsection{Attacks against specific people}

The authors of humour magazines did not shy away from using too personal a tone, especially in the case of certain well-known candidates because the candidates represented entire parties in the national media. Presumably, this strategy is less applicable in local press where personal relations are the most essential. Mór Jókai, a popular writer became the target of attacks of the governing party. He was considered a good novelist but an incompetent politician. Taking this a step further, it was assumed that if one of the leftist candidates was not suitable to be a representative, it could question the expertise of others, too. He was also accused of bribing his voters with food and drink and, in order to question his popularity even further, a caricature in the Borsszem Jankó referred to him only as someone daring to give talks only to children who did not even have voting right. In another example, he could only hold on to two drunken voters, a Jewish and a Hungarian. The caricature suggests a fall in the number of Jókai supporters; moreover, their small number and drunkenness degrades the entire opposition (Figure 1).

The joke is built on the potentially ambiguous meaning of the word "unstable": in the caricature, drunken people have a hard time standing straight but the caption refers to the voters who cannot decide. ${ }^{4}$ The novelist was well-known in his precinct, Terézváros among the Jewish, so the governing party often depicted him as becoming one of the Jewish and being circumcised. 


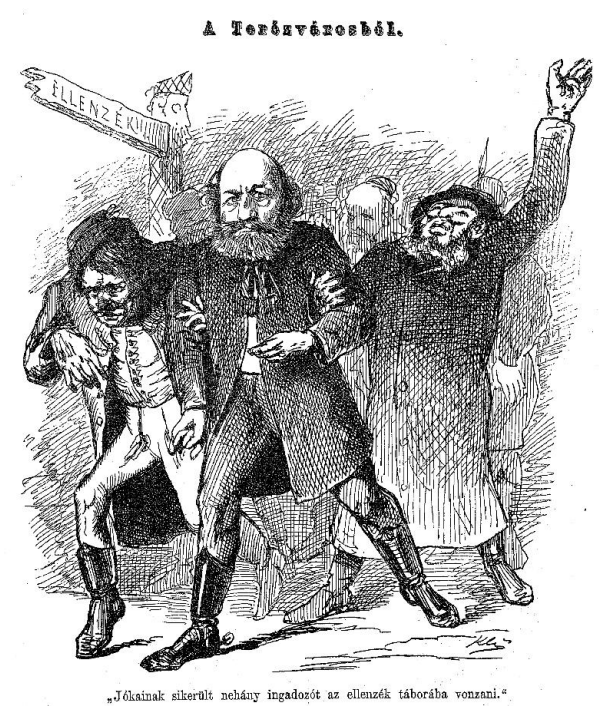

Figure 1. "From Terézváros. 'Jókai could convince a few of the unstable ones to join the opposition."” Source: BJ, 14 February 1869.

The motifs of becoming Jewish and being circumcised appeared in 1872 as well. Jókai often appeared in the humour magazine of the governing party, and since he had no other choice but to try his luck in more than one precinct in 1872, he became the target of sarcastic writings and caricatures. His situation was made even worse by the fact that he was affiliated with Ede Horn (1825-1875) who also failed in various precincts before being elected in one. Jókai failed in Terézváros, and Horn belonged to the Israelite denomination, so it is not surprising that a Jewish-related trope was chosen to illustrate and mock their failures. Horn and Jókai can be seen as Jewish men, wandering from precinct to precinct, having no rest just like a Jewish man in a story of the Bible who was cursed by Christ to be a wanderer until the return of the Saviour (Figure 2).

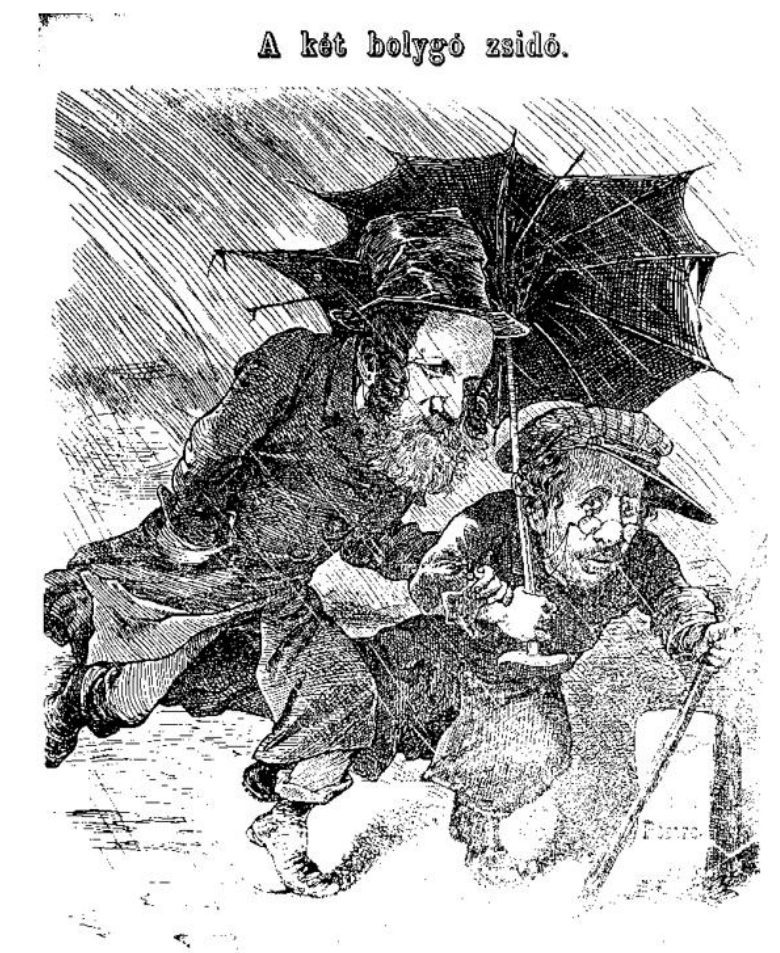

Figure 2. "The two wandering Jews." Source: BJ, 16 June 1872. 
In connection with Horn's and Jókai's failures, another pun was also recurrently applied. Since they failed in several districts, they were thinking about where to run for representatives while looking at a map. Horn suggests going to Bukovina. At another time they are preparing to go to Bucharest. In Hungarian, in the first syllable of the geographical names of the North-Eastern region (Bukovina) and the Romanian capital (Bukarest) one can find the root of the Hungarian verb bukni (to fail), and it is this phonological similarity that the authors of the paper relied on and took advantage of (BJ, 23 June 1872; 30 June 1872).

The answer to the opposition to such attacks of the Borsszem Jankó is less intense: the comic papers of the opposition usually tried to emphasise in their texts in each electoral district, by means of publishing several songs, often with the inclusion of the names of rightist candidates, that the leftist candidates were more suitable as they are the ones who should be chosen. They did not put caricatures of candidates of the governing party on their title-pages, so they did not focus solely on one person whom they kept on attacking like the Borsszem Jankó did against Jókai.

Deák, on the other hand, who was a candidate in the capital, was often attacked even during the elections by the Ludas Matyi, using his family name to create puns. As a common noun in Hungarian it means "student", referring to someone who speaks Latin and is welleducated. The punch line of the stories in the magazines is usually that he is in fact not as educated and smart, even questioning his mental health for having signed the Compromise. Another common joke is based on Latin as a dead language, therefore, those who speak Deák's language, that is, those who support the Compromise, will inevitably fail as they represent the past, not the future. Yet another joke refers to students as being underage, which leads to the following punchline: Deák's party will fail since their leader is but a minor. Deák is made responsible for the facts that Kossuth cannot come home from emigration, that Hungary is not independent and not a happy country (LM, 11 October 1868). Facing this is the positive figure of Kossuth who has become a father figure, who is close to the nation and is a loved and respected leader. Even though the Borsszem Jankó also tries to popularise the members of the government and candidates, as well as Deák and the Compromise, a person like Kossuth, who evoked such strong emotions, was not present (LM, 31 January 1869).

All in all, this humour tool, namely the systematic attacking of the candidates of the opposition, was used most consistently and most consciously by the Borsszem Jankó, exemplified by their well-made caricatures. The Ludas Matyi frittered their offenses away, except for occasional attacks against the symbolic figure of Deák, and the Az Üstökös stayed away from ridiculing specific politicians.

\subsection{Standing up against the principles and symbols of the opponent}

Both of the opposing parties had principles and political symbols that became subjects to sarcasm in the papers of the opponents. In the case of the right, it was the Compromise and Ferenc Deák who was often referred to as the "Wiseman of the nation" by his contemporaries as well. And on the other side there were the anti-Compromise ideals, Hungary's independence, Lajos Kossuth as the Moses of the Hungarians, that is, as a saviour sent by God. The Borsszem Jankó talks ironically about canvassers having to popularise those antiCompromise ideals because success is guaranteed that way, for example, among the young. A good tactic is the following: "Freedom, freedom, freedom! This is what has to be repeated in front of them. The government has to be degraded; we have to shout that there is no freedom of press and that we are prisoners" (BJ, 23 February 1868). This is how the paper of the governing party calls attention to the fact that it is easier to take part in an election campaign as a member of the opposition, it is easier to blame the government for certain moves they 
made, and it is much more difficult to put together a programme. The words freedom and captivity summon memories of 1848-49 because the iconic poem of the bloodless revolution of 1848, Sándor Petoffi's National Song, contains the following well-known lines: "Should we be prisoners or free? / This is the question, choose!" The times before 1848 were interpreted by the contemporaries as imprisonment, but the time of neo-absolutism (Bach-era, 1851$1859)$ and the Schmerling-era (1861-1865) were also referred to in the same way. Freedom and slavery often appears in poems working with easily definable opposites, too: if the governing party stays in power, it can only mean slavery, serving Austria, instead of the much-wanted freedom.

The editor of the Borsszem Jankó tried to label remarks of the opposition as demagogic and untruthful when they suggested that the Hungarians can talk about their anti-Compromise views at the elections and when they implied that there is no freedom or freedom of press. The Borsszem Jankó captures the essence of the opposition's popularity in the fact that their supporters and voters are credulous, under-educated and can easily be influenced by demagogic ideas. It also aims to point out that, apparently, their promises are false and cannot be realised, so they are not trustworthy and should not be voted for. This is how they write about leftist canvassing in a poem: "They call you to the left; the people of Vásárhely!5 / And then they lie and promise and with their sweet words / Will push you onto thin ice, you will see, do not run to it" (BJ, 21 February 1869). The opposition tried to fend off these attacks in different ways. One of their tools included the texts in which candidates of the governing party made unattainable promises. According to one of them, aspirants of the right are willing to promise anything: there will be a Hungarian army consisting only of officers, everybody will be able travel free by train, children will not have to go to school and lands will be granted (Ü, 30 May 1868). They, however, applied another method more often: papers of the opposition usually talk about how little the government has achieved and incite antiCompromise feelings. It can be an effective tool of mobilisation when the achievements and goals of the other side, of the government, are presented in negative ways, since, hoping that the negative course of events can be ceased, people did take part in the voting processes. The opposition used it to their advantage because it was much easier to feed anti-Compromise sentiments instead of trying to convince the already dissatisfied Hungarian society of the advantages of the Compromise.

Poems of the opposition concentrated on recurrent elements which could be used to evoke anti-Compromise feelings: the rejection of the quota, the policy of common affairs, the cancellation of high taxes, denying the offer to pay part of the national debt, promoting an independent army and a central bank. Similes and symbols with negative connotations are quite diverse in the papers of the opposition. The Ludas Matyi, for example, says that "the worm of common affairs is eating away at the country" (LM, 9 June 1872). The Compromise is meant by constitution of common affairs, which is also called a "devilish riddle". Having accepted this, Deák and his party dug a "deep grave" for the nation, leading to a system even worse than those of Bach or Schmerling (LM, 14 March 1869). Both of those eras were characterised by regulatory government and absolute sovereignty, without any constitutional features. The governing party, naturally, protests against this, claiming that the aims of the left are unattainable and unfeasible. The Az Üstökös disagrees with this when it says that, according to the government, in the programme of the opposition "there are many who cannot be taken. That's right, as an example, the Hungarian regiments." In 1848 it was demanded that the monarch should bring back to the country the Hungarian regiments serving abroad, and he should not be able to deploy them abroad without the consent of the parliament. (The Compromise regulated the question in connection with the deployment of the army.) The pun comes from the Hungarian participle "kiviheto"" (lit. 'exportable'), 
meaning in the first place that something is taken from somewhere and on the other hand, it can mean "feasible", "doable" (Ü, 27 February 1869).

Apart from an independent Hungarian army, to which people felt emotionally attached to because of the events in 1848-49, Hungarian folk costumes also became symbolic. So, it is not accidental that a common symbol of the fights against the Compromise, not only in connection with the elections, is the Hungarian folk costume, contrasted with the dress coat and top hat, which symbolises the Austrians. The Hungarian folk costumes are related to the values of 1848 and Hungarian freedom in general, while later, in the 1850s and 1860s it was the symbol of passive resistance against neo-absolutism and the protest against a nonconstitutional system.

As its counterpart, the dress coat and top hat represented the repressing power of Vienna. This pair of opposites appeared in the motivational poems of the Ludas Matyi as well: "Hungarian hearts in Hungarian clothes" (LM, 14 March 1869), beating for Kossuth and the nation, while those who signed the Compromise wear dress coats as supporters of Vienna. Evidently, this symbol was capable of stirring up emotions. When contemporaries accused Deák and his party of taking off their Hungarian clothes, they, in fact, were referring to treason. Costume is also in the centre of caricatures operating with opposites (Figure 3).

\section{A JOBBOLDALI JELÖLT.}

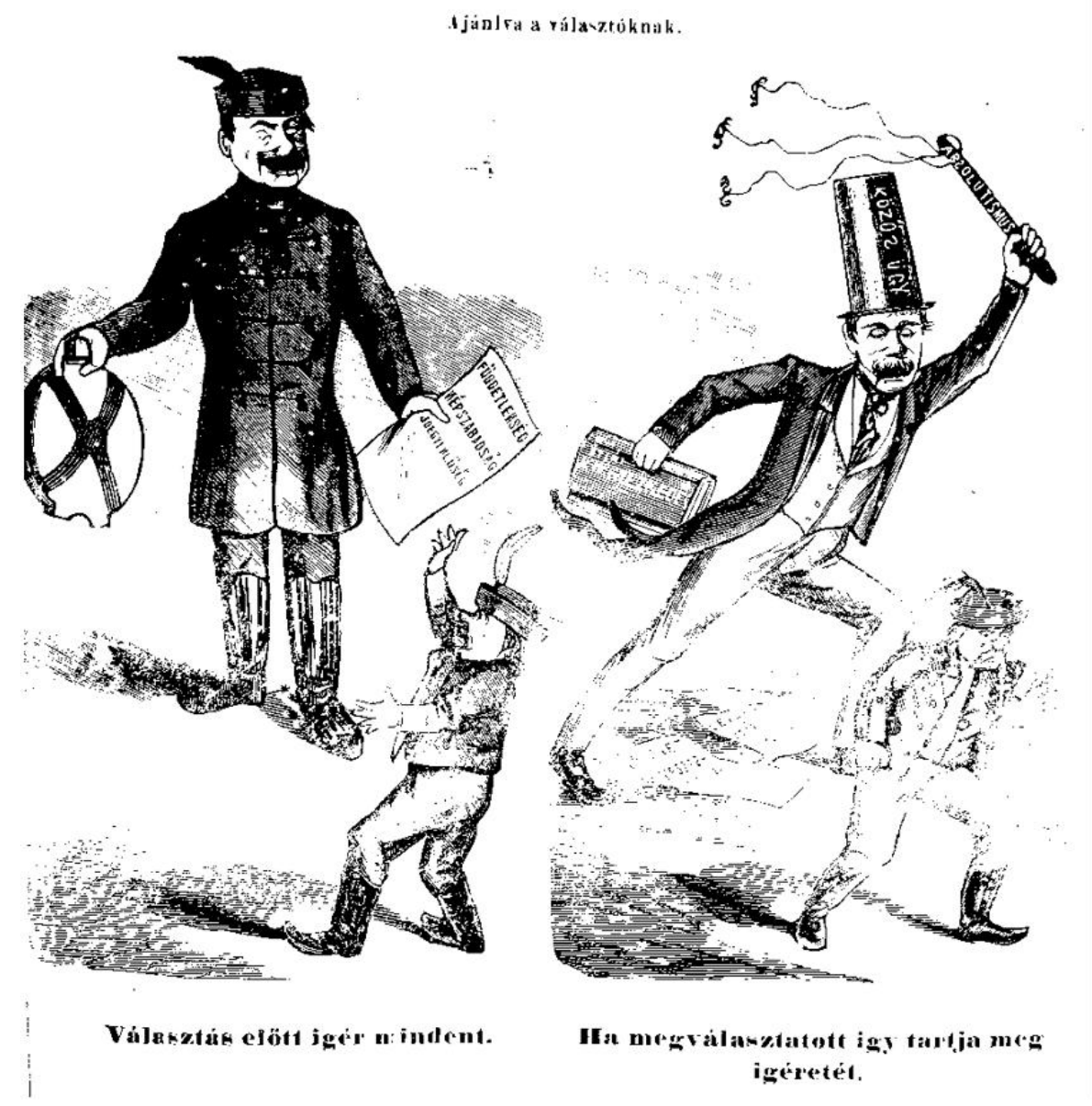

Figure 3. "A candidate of the right. Making offers to the voters.

Before the election he promises everything. Once he is elected, this is how he keeps his promise."

Source: LM, 5 May 1872. 
The candidate of the right, in a deceiving fashion, fools his voters with promises more characteristic of the left (independence, equality of rights), dressed in traditional Hungarian clothes, smiling. However, after being elected, he transforms, puts on a dress coat, "common affairs" is written on his top hat, his book is titled Compromise instead of Independence, and he holds the whip of absolutism in his hand, with which he drives away the Hungarians. The caricature calls the attention of the supporters of the left to the false promises of the right since they are not the power that can guarantee independence, hence their politics equals absolutism.

Similarly to the motif of the Hungarian costume, any other tool evoking national sentiments could be just as effective. They appeared during both the 1869 and 1872 elections in humour magazines of the governing party, encouraging people to vote, in case they are unsure, for the governing party. Leftist parties joined forces with some (radical) candidates of the non-Hungarian minorities, hoping that they would be able to increase the number of their supporters and the likelihood of their success. The Borsszem Jankó took advantage of this and in exaggerating articles painted a false image of the opposition as if they wanted to give a significant part of the country to Romania if they won; in other words, they would dismember the area of Hungary and donate parts of it to the minorities, which equals treason. The situation, of course, was nothing like this; it was nothing but a campaign tool from the side of the governing party. At the time, some social layers of Hungary were filled with anti-minority feelings ${ }^{6}$, this is what the Borsszem Jankó utilised (BJ, 28 April 1872; 14 February 1869). This tactic is remarkable since we know that in precincts where Hungarians were the majority, fewer people supported the Compromise than in peripheral regions of minorities or in regions with mixed population. The government party had no chance of winning without the support of these regions (Toth 1973: 138).

\subsection{Listing well-known anti-theses}

Simple, easily understandable dichotomies, e.g. honest vs. corrupt, patriot vs. traitor, helped distinguish and characterize the party's own and the enemy's power; therefore, the differences between the two groups were highlighted and even exaggerated. These opposites were also used by the authors of humour magazines. Songs published in the paper of the extreme left emphasised what a patriot and how honest their candidate was; they pointed out the corruption of the governing party, and the idea that, in their opinion, Deák sold the country in 1867. To accentuate their views, they draw a parallel between Deák and Artúr Görgei (1818-1916), who was another traitor in the eyes of their contemporaries for giving up the fight at Világos in 1849 against the Austrian-Russian overpower. In the same way, as they say, Deák and his party gave up the fight against the monarch. Using the patriot-traitor opposite, the authors try to appeal to the emotions of the public, which is considered a much more successful strategy in the literature on elections as opposed to rational arguments (Lutter \& Hickersberger 2000: 85-86). The label "traitor" becomes a permanent element when talking about candidates of the right, an attribute powerful enough to have a mobilising effect since nobody wants to see a traitor sitting in the Parliament. Generalisations and oppositions are often repeated in order to bring about associations and become stereotypes that might be transferred to other candidates as well, which are all vital strategies in an effective campaign. A supporter of the left could potentially remember the word "traitor" when hearing the name of any candidate of the right as he had read it or heard it several times. Unlike the treacherous right, a latter prime minister, a centre-left politician at the time, Kálmán Tisza (1830-1902) can take pride in having a "true love for his nation". Another candidate "lives and dies for the country", yet another is associated with the "saint relic of patriotic honesty" (LM, 20 September 1868). The descriptions of the honest, trustworthy and 
patriotic leftist versus the dishonourable rightist were illustrated in a caricature by the artist of the Ludas Matyi (Figure 4).
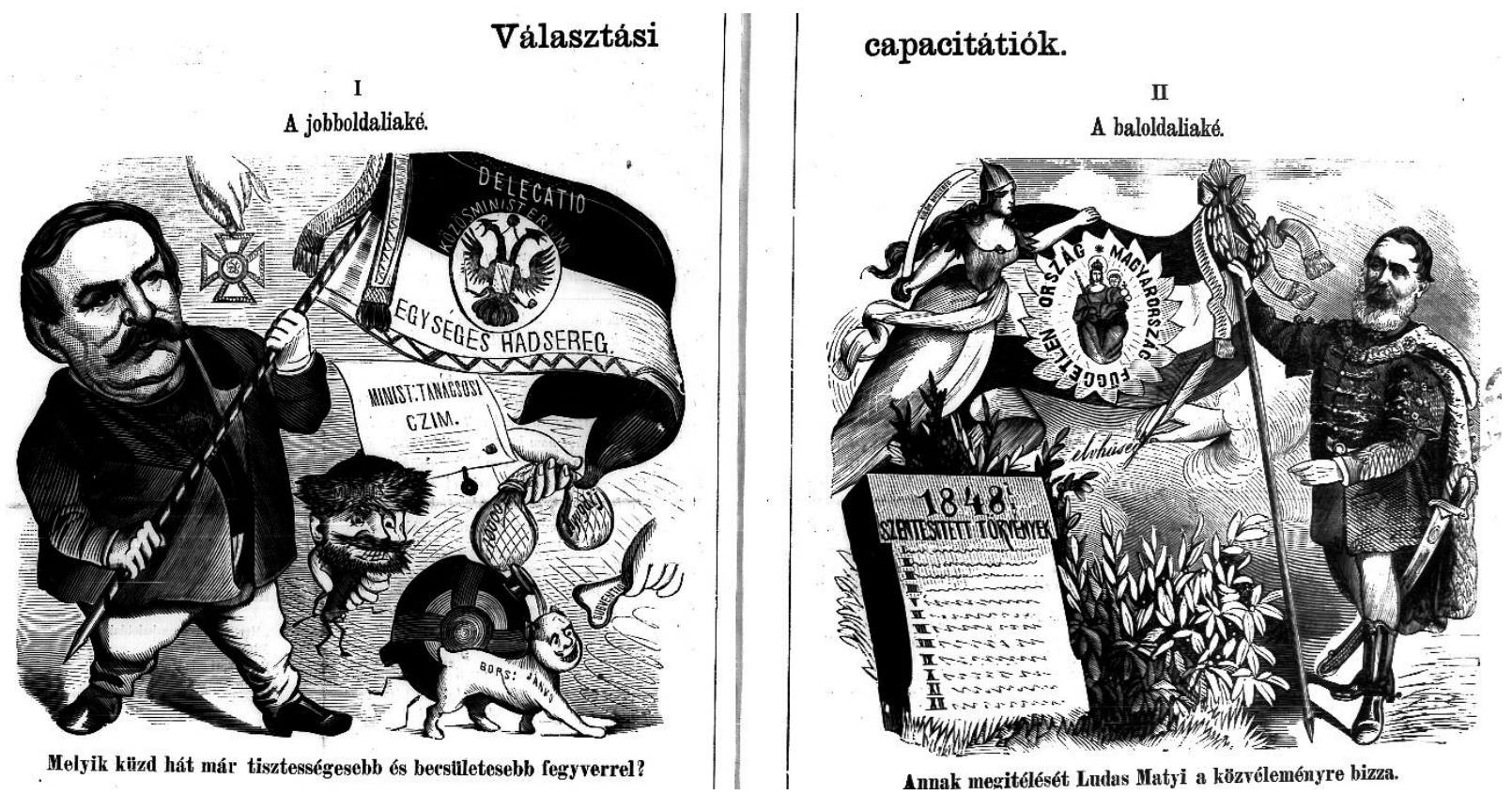

Figure 4. "Election choices.

I. The Right

II. The Left

Which one of them fights in more trustworthy, more honest ways? The judgement of this is left to the public opinion of the Ludas Matyi."

Source: LM, 21 February 1869.

In the image Deák and Kossuth are facing each other and they are both flying flags. The caption "joint army, delegation, common ministries" is written on Deák's flag. There are awards and titles beside him, which, according to the opposition, were given to him as a graft from the government. The motif of money also appears, implied by the images of bags filled with money and in the form of subvention given to Borsszem Jankó, who is depicted as a puppy. Wine is spilling from a flask and a "bugaboo" is being held onto by a hand. The "bugaboo" resembles a Russian soldier, and although the half-human-half-bug figure is holding a bayonet, it does not look too scary because of its small size and frightened expression. The Russian soldier once again refers to the failure of the war of independence, and warns about what would happen, according to the rightist press, if the left succeeded: the Russians would attack the country again, but they can keep the czar under control as long as they can remain in power. Kossuth's flag reads "independent country", with a female figure beside him, embodying the independent army, and table of stone showing the laws of 1848, which are defining elements of the era, representing the civil transformation of the country into a society of bourgeoisie. The picture is pathetic, and it also contains a Biblical motif: Moses also received the Ten Commandments on tables of stone. Kossuth sends his "ten commandments" to the Hungarians, so as not to let go of the laws of 1848, in which common affairs are not featured. Thus, Kossuth is no longer illustrated as a father figure but much more of a transcendental one.

"True" Hungarians are in an adversary relationship with the government because they made a pact with the "German", that is, with Austria; consequently, Hungarians became subjected to Austria both in a financial and military sense. Members of the governing party 
are mocked as "schwarzgelbs", referring to the flag of the Habsburg Empire (as it was black and yellow until 1867). The heraldic animal of the Habsburgs, the eagle, also had the same function, since negative associations (absolutism and the failure of the war of independence) were attached to it, so the opposition could use it as a further symbol in their campaign. A topos is connected to this image which suggests that the new system is just as bad as that of Schmerling or Bach, or it might become just as horrible over time. The names of both these Austrian-German politicians (Schmerling and Bach) became swearwords in the press of the left, contributing to turning people against the right.

Papers of the opposition call attention to other supposed negative features as well. The author of the Ludas Matyi states that candidates of the governing party "do not have much wit" (LM, 10 November 1867), suggesting that they should take this into consideration if they take part in the upcoming elections. Such statements, although included in humorous anecdotes, are quite generalising, as they strive to put the label of inept on each of the candidates of the governing party, making them seem to be the wrong choice to vote for. This campaign tool is similar to the one where Deák and members of his party are called silly, as an opposite of the "Wiseman of the country", although this one implies an even broader generalisation.

In terms of the use of fixed labels, and for the sake of those who must have understood, the left operated with more effective phrases, as the patriot-traitor opposition must have had an obvious impact on people's emotions.

\subsection{Standing up against the press of the opponent}

As it has already been referred to in the introduction, contemporaries had the impression and widely discussed the fact that the press had more and more influence: political papers were read by more and more people, and this had an effect on the opinions of a growing number of people. ${ }^{7}$ Therefore, it is not by chance that even humour magazines reflected on the exaggerations of daily papers with regards to the election campaign. Humorous papers of the opposition protest against the claims of the government in which the opposition is already the one losing, even though the elections have not even started. The message of the press of Deák's party must have been very clear for the contemporaries: if the opposition cannot win, if the voters are told that their failure is certain, it is no use voting for a candidate of the opposition. This can dissuade unsure voters and convince them to support the right, and it also makes the mobilisation of the leftists much more difficult. A recurring element in papers is a protest against this, saying that, very much on the contrary, the popularity of the opposition is growing. Papers of the opposition denied statements of the governing party about their own victory in some of the precincts being already guaranteed. They tried to come up with similes that imply that this piece of news is absolutely impossible: "the success of the governing party is as sure as Ludas Matyi being appointed as the Pope in spring" (LM, 24 January 1869).

The government's media policy was heavily attacked by the opposition, not only during elections. In the Ludas Matyi reports were published about an imaginary meeting. Gyula Andrássy is having a conversation with the editors of those subsidised press products that were loyal to the government. He raises the following question: "what if we fail?" (LM, 27 September 1868). The editor of the opposition suggests that the right are secretly afraid of failing, even though it is not something the government talks about publicly, and they must discuss such things during non-public meetings. To prevent that from happening, Andrássy appointed the task and expressed his dissatisfaction with the governing party's campaign in the press: "the opposition has to be dragged in the mud [...] I know you can do better." The texts, on the one hand, mention the unequal amount of media appearances, claiming that the 
government has more opportunities, thanks to the papers they sponsor; on the other hand, they describe the peculiarities of the party press and the system: in the event of their loss, press relations would also be re-arranged.

The Borsszem Jankó called attention to the rude tone of the opposition's press during the 1872 election campaign. According to an extreme-leftist text attacking the governing party, as cited by the Borsszem Jankó, one of the candidates of the right "feasted on child-shredding Deák-party sausages" (BJ, 16 June 1872). Another example for such rumours and untrue news is a poem: "And the news spreads that a butcher of Deák's party / Serves human meat at his house in abundance / Those who enter there, remain silent forever / For the butcher out of their flesh cooks his dinner" (BJ, 16 June 1872). The opposition's press does not shy away even from the extremes, from the charge of murder and cannibalism, says Ágai disapprovingly.

It was mostly the humour magazines of the opposition that utilised the tool of presenting fake reports about how the government's daily paper talked about a meeting of a candidate from the opposition and the governing party. (This tool of humour, bringing opponents face to face with each other, is a frequently applied method in caricatures as well.) In 1869 only the opposition took advantage of this tool, then in 1872 the Borsszem Jankó also published similar texts. The Az Üstökös reports that a paper of the right writes the following about an event of the Deák Party: the candidate's speech, that he delivered in front of a "tremendous mass", could have brought shame even to a rhetor from ancient times, and then it was all followed by an elegant dinner accompanied by singing, after which they all went home. The left, however, claims that he delivered his speech at a weekly market on purpose so that he could address a lot of people. Free wine and steaks were served in the pubs, and the drunk citizens were vandalising the streets until late at night. The paper of the Deák Party did not fail to report on an event of the left either: the canvasser delivered his speech on Sunday on purpose as well so that the people coming out of the church would hear it. There was no banquet, and only a few people spoke up during his oration. The audience got angry, so the candidate of the left "decided to retreat" (Ü, 3 January 1869). On the contrary, the paper of the left claims that there was a peaceful procession with many participants, carrying torchlights, and people were listening to him and were singing the national songs, but they did not have a feast. The author made fun of the press of both parties which attempted to influence the voters with exaggerated reports, thus mediating an atmosphere. We can see how the Az Üstökös warned its readers that the papers of both parties talked about these events in very biased ways and used similar topoi. They both claimed that the event of the opponent did not have much audience, that it was disorderly, whereas when talking about their own events, they applied a much more elevated tone, the people sang the national anthems, there is peace and the audience is large.

\subsection{Judgment of the role of the Jewish people as a campaign tool}

Besides the press, the contemporaries were also afraid of a social-denominational group, the Jewish, because of their unpredictable reactions and voting attitude. The first Hungarian government proposed a bill on the civil and political emancipation of the Jewish population (1867). This meant that the Israelites who used to be stripped of their rights became voters and ones to be voted for. Many of them befit the property or intellectual census, especially in the cities, and from the perspective of elections, it was something to keep in mind that they were not necessarily committed to any candidate through family or geography. The party the Jews chose to vote for mattered a lot to both sides as they were seen as mobilisable voters. This is why the $A z \ddot{U} s t \ddot{k} k \ddot{s} s$ stated that "In the elections of the upcoming year, they won't be a despicable group" (Ü, 28 December 1867). The opposition expected and was also afraid that 
the Jewish people would vote for the candidates of the governing party, as a way of thanking them for the emancipation.

According to the humour magazines, the Israelites adapted quickly to the society of the majority and utilised their newly acquired rights, taking part in the election campaign. Many caricatures feature a happy, heavily gesticulating Jewish person as a canvasser. It is not uncommon either that the innkeeper, who previously only provided the venue for the events, becomes the canvasser himself. One can see the same in the caricatures of the Borsszem Jankó: before the emancipation of the Jewish, the innkeeper Abraham is happy to be excluded from the drinking and fighting of the Hungarians, he only makes profit. After the emancipation he also becomes a part of the events of the elections, he will be beat up (BJ, 3 January 1869). The Jewish people, in the above demonstrated fashion, also appear in humour papers in connection with Jókai and Horn, and also, as a reflection on the stereotypes of the time, as the creditor of canvassers and candidates.

\subsection{War metaphors}

When it comes to talking about election campaigns or preparing for voting, we tend to use metaphors related to warfare even today, although they had a different topicality in 1868 and 1869 as it was the twentieth anniversary of the Revolution of 1849 . The idea, or danger, of a revolution must have had more actuality than one can imagine today. Ágai's paper regularly brings up the threat of another uprising: if the left won, the time of peaceful development would be over because its pledge is Deák's government. The press of the left protests against the risk and the start of a revolution, although it also adds that taking responsibility for a revolution would still be much more patriotic than supporting the Compromise. If a revolution broke out after the victory of the left, suggests the Borsszem Jankó not for the first time, Russian armies would come to the country to stop it, which would cause loss, national grieve, trauma, and a feeling of humiliation because of the defeat. Both these elements appear in 1869 and 1872 as well: the right keeps on scaring the voters with the threat of a Russian attack with the accusation of starting a revolution. The magazine of the governing party mobilised voters who were dissatisfied with the Compromise by depicting what would happen if the opposition won, thus evoking their personal losses. Awakening personal fears in an individual could be a useful tool in a campaign since it is a more tangible experience than, for example, the death of a nation, which was a widely-used rhetorical element at the time.

When describing the events of the left, the Borsszem Jankó's authors liked to use terms related to military activity, which increased the fear of a potential revolution. It can be read that voters of the Deák Party were attacked and conquered by the centre-left in a town, while people of the governing party were beaten to death at another place (BJ, 28 February 1869). The opposition did not want to stay behind either when it came to verbal fights. The Ludas Matyi, for example, talks about elections as wars: the right walk around with swords in hand and line up cannons in the capital. According to chivalry confessions of a member of the Deák Party: "We've got the money, wine, office and trick, / Guns, bayonets, prisons, / All of these are saint and free, / Leading to the finish line" (LM, 21 February 1869).

Armed forces make "free" elections possible for the governing party: armed soldiers are blocking the roads, the police are attacking the opposition, they are stabbing each other in the stomach and hitting each other with sticks; and this would be the peaceful right, striving for order instead of a revolution. The regular representation of such fights is also connected to the motif of feistiness. The following caricature illustrates the behaviour of some members of the opposition. The scene looks more medieval than modern, although the democrats are said to work abroad (Figure 5). 

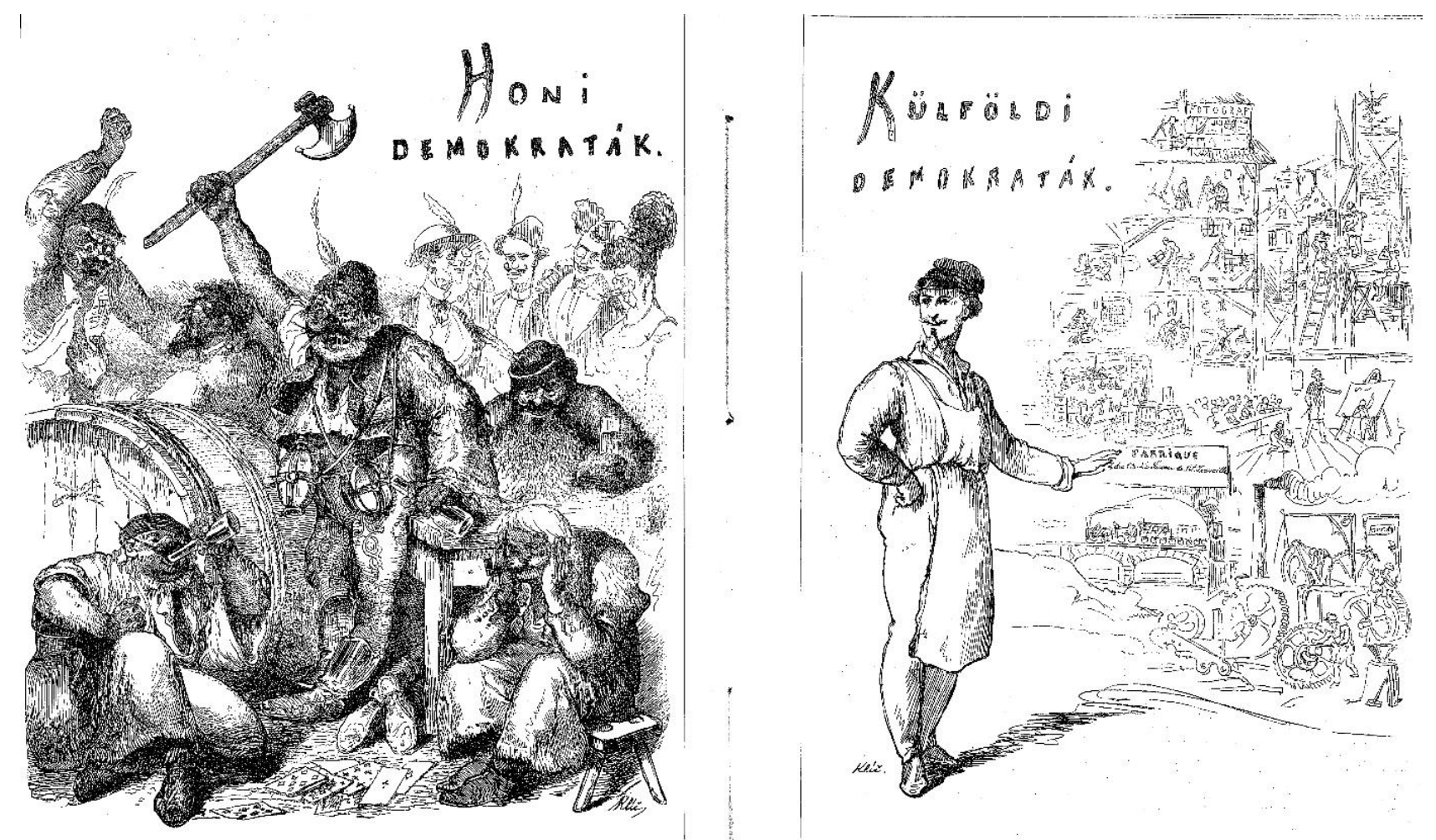

Figure 5. "Democrats at home”, "Democrats abroad”. Source: BJ, 3 May 1868.

These sarcastic pictures suggest that if they became the majority in the new Parliament, there would be nothing left of the constitutional system of the Compromise because all they can do is destroy, since they cannot build, even their lifestyle is morally questionable and to be rejected. The press of the opposition also used fighting as a motif to degrade those who support the Compromise: members of the government are beating up each other. Besides aggressive verbal utterances, physical violence is also present in the caricatures and the texts both on the sides of the opposition and governing party.

\subsection{The critique of the campaign methods of the opposition}

The Borsszem Jankó published a critical and ironic article with educational purposes about how canvassing "should" be done during the following elections and how leftist politicians usually do the canvassing: "A glass of wine, some steak, I use these kinds of moral tools to convince people" (BJ, 4 October 1686). The author suggests that only the candidates of the opposition bribe people this way, whereas one knows that during the elections both parties applied such methods at the time of the Dualism. There is, of course, an answer to the accusations. Parties of the opposition are not afraid of being challenged according to their own humour magazines, and they use honest tools for campaigning. It is the governing party that organizes feasts with free food and drinks; it is only them who apply various forms of bribery. In a caricature one can also see how the right and those canvassing for the governing party drank heavily, while the left canvassers are portrayed as handsome Hungarians lads, which paints a quite obvious contrast between the two parties (Figure 6). 


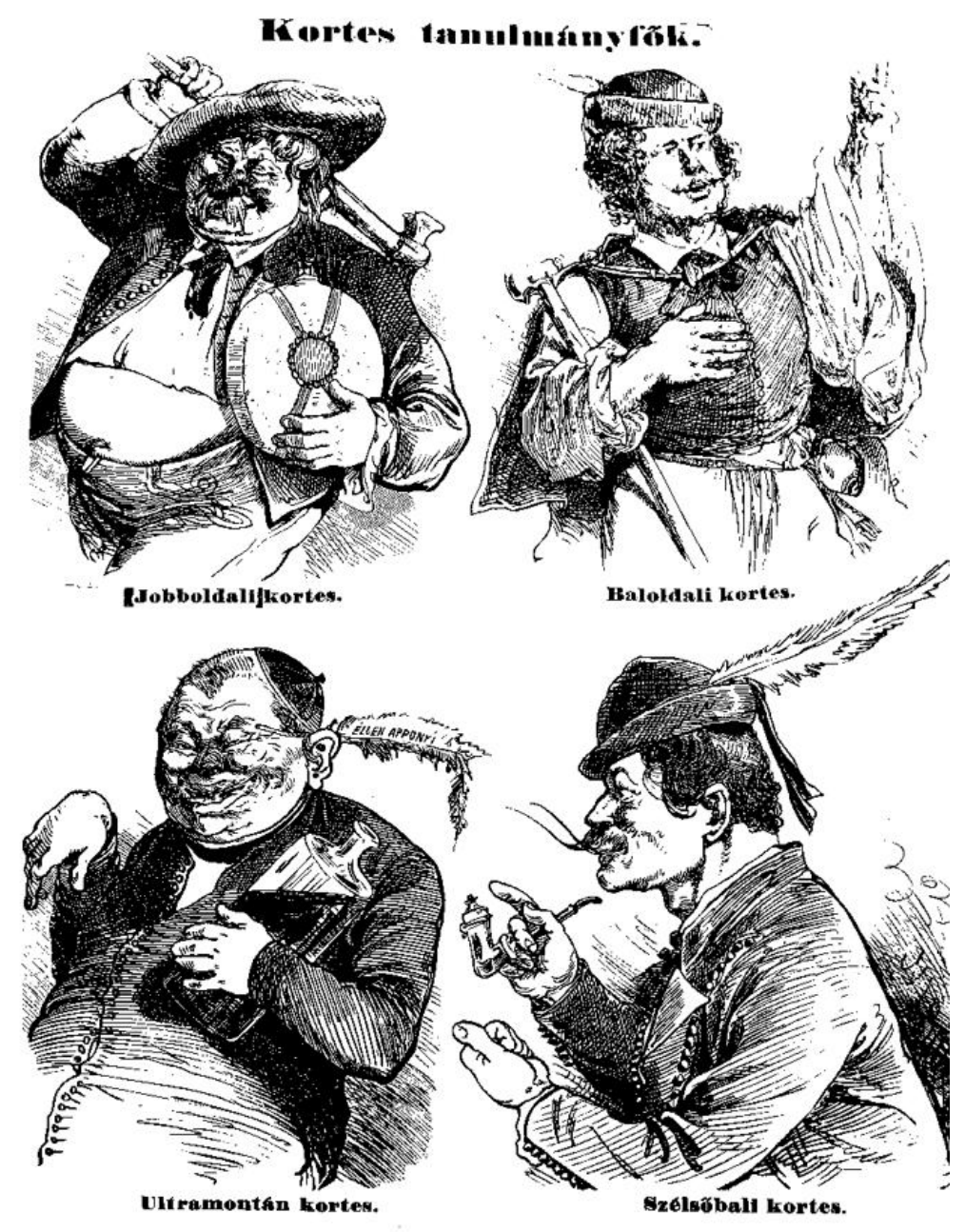

Figure 6. "Leading canvassers.

Rightist canvasser.

Leftist canvasser

Ultra-mountain canvasser

Extreme leftist canvasser."

Source: Ü, 22 June 1872.

In a paper of the extreme left, names of the rightist canvassers are rather telling: "Paul Sipping, Andy Thirsty, Joe Flask, Steve Winedrinker, John Glutton" (LM, 31 March 1872). All of these surnames refer either to alcohol or feasts and eating too much. The large amount of wine consumption on the governing party's side also appears in songs, along with their untrustworthiness shown by the assumption that the Deák Party "buys its voters for money." The leftist candidate, however, says the following: "We don't do canvassing for money; we do not sell our bodies and souls" (LM, 15 November 1868).

\section{Conclusion}

The importance of the elections, how much they raised the interest of the population yet how damaging people thought them to be is demonstrated by the fact that in 1872 authors compared election movements to the eruption of the Vesuvius. The comparison is not by accident, the volcano did erupt in April 1872. The Ludas Matyi, utilising that recent event, 
summarised everything that should be known about Hungarian elections in the following way: "Here, the Vesuvius of elections also erupts every three years and it only differs from the one in Italy in that it doesn't breathe fire but wine and of course that here lava covers the whole country, not only a village or two" (LM, 5 May 1872).

Lutter \& Hickersberger claim that in order to successfully mobilise voters it is vital that voters must feel personally motivated. This was realized in 1869 and 1872 as both the voters and those not having the right to vote wanted to voice their opinions about the Compromise or at least about certain representatives, although the recently reintroduced parliamentary system seemed new still. Another criterion of successful mobilisation is to be easily distinguishable from other parties (2000: 208). In 1869 this was exactly the case, but in 1872 the centre-left's approach of the governing party was still at a primary stage, so we can still say that parties and ideas represented by them could be easily separated. This is why the application of bipolar opposites is so characteristic both in caricatures and texts. Fights for voters even today is still more intense in political systems where there is no tradition of coalitional governments (Tsakona 2013: 102), the possibility of which did not exist at that time in Hungary.

The 1869 and 1872 election campaigns and the critique of the Compromise is characterised by exclusiveness in humour magazines. Negative features were attributed only to one of the parties, the opponent: they are corrupt, violent, they make false promises, their views are treacherous and their leaders are inept. The images and texts of humour papers illustrate the polarisation of the Hungarian society. Moreover, they imply that the opposition does not have many supporters and they are ignorant and unfit for the leading of the country so there is no point in voting for them, since their candidates are bound to fail. No matter which side was popularised by a given humour magazine, their campaign tools were similar: they tried to ridicule the leading politicians of the other party and they attacked them and their ideals. As a characteristic of the genre, they protested against the standpoint of the rival in exaggerated ways in texts and images. The effects of the powerful wars of press before and during elections cannot be measured retrospectively by present-day researchers; however, it is clear that the heightened mood and the political activism of the public is reflected in the columns of humour magazines. It is worth referring to the results of modern research in connection with the growing aggression and the coarse style of the press. Based on current research, it becomes obvious that humour used to play a huge role in political discourse which was becoming more and more aggressive. These aggressive attacks against the opponent call too much attention, and the answer to them are usually just as verbally aggressive (Tsakona 2013: 102).

One can also conclude that authors used typical genres related to the election campaigns in humour magazines. One can find dramas adopting scenes from elections, poems, fake news, reports, and anecdotes. In 1872 the number and the subjects of the caricatures were much larger, although one can find differences as well during the two campaigns. In 1869 the names of Schmerling and Bach were mentioned more times by the authors of the opposition than in 1872. The reason for this is perhaps that the "threat" during the three years between the elections had become pointless, as it turned out later that a new absolutist system was not formed. However, in 1848 there was a frequently appearing notion, which, unlike the ones recalling the absolutism, was seen as positive by Hungarian society because it reminded people of the Laws of April and the civic transformation of the nation, not the war of independence. Apart from the political symbols connected to either the negative or the positive experiences of the past, which were undoubtedly seen in the same way by the voters of both sides, various other, controversial symbols also appeared, such as Lajos Kossuth, Artúr Görgei, Ferenc Deák, and the ideal of the 1849 independence and revolution. 
The humour magazines (except Borsszem Jankó) seem to be rebellious, they protest against the Compromise, the readers could feel that they do something against the new political order, but this kind of humour can cover the powerlessness of the society against the Compromise (see Nieuwenhuis 2017 for similar conclusions). The well-developed political humour can be a symptom of low political assertiveness of the society.

In conclusion, I have demonstrated what kind of tools were used by humour magazines when the genre really became popular in Hungary, at the time of the two election campaigns following the Compromise of 1867, by analysing the similar and different methods and symbols of the parties and the campaigns. Researchers today can hardly tell from the texts and images of the magazines what the contemporaries found funny, humorous or offensive when representing a political opponent. The questions of how the role of humour papers changes, whether they still take such an active part in campaigns, and if humour and sarcasm as well as the entire humour magazines themselves prove to be effective tools during election campaigns would all be worthy of further research.

\section{Acknowledgements}

Supported BY the UNKP-17-4 New National Excellence Program of the Ministry of Human Capacities.

\section{Notes}

${ }^{1}$ Lajos Kossuth was the politician who, during the Revolution in 1849 , declared the dethronement of the Habsburgs.

${ }^{2}$ No law obligated the king to choose the prime minister from the most successful party. In Hungary, it only happened once in the $20^{\text {th }}$ century that the prime minister was chosen from the losing party since it was an anti-Compromise party that had won the elections.

${ }^{3}$ In this paper I will abbreviate the titles of comic papers as follows: Borsszem Jankó (BJ), Ludas Matyi (LM), Az Üstökös (Ü). The cited caricatures are examples, each analysed issue contained more caricatures on every topic of the analysis.

${ }^{4}$ According to case studies, the most recurrent form of political humour in the 20th century was puns (see Tsakona 2013).

${ }^{5}$ A city in South Hungary.

${ }^{6}$ Non-Hungarian national movements demanded regional autonomy from 1848 . The liberal Hungarian political elite, who based their views on personal rights of freedom and did not agree with collective rights, was not willing to comply.

${ }^{7}$ Researchers admit that the press has become the "the fourth branch of power", though its effect is estimated more carefully than in the 19th century. Results in psychology have pointed out that people at the time attributed an overly high level of importance to press campaigns, but the processing of information in the human brain is much more limited than they thought (Sipos 2011: 42-43). Linguistics and communication-theoretical literature also supports this fact, especially in the case of humour and visual elements. The observer might not find the visual or textual elements humorous or might find those ones funny that were not intended to be at all (Sanz 2013: 11).

\section{References}

A Pallas nagy lexikona (1897) [The great lexicon of Pallas]. vol. 16. Budapest: Pallas. 
Boros, Zs. and Szabó, D. (1999). Parlamentarizmus Magyarországon. Parlament, pártok, választások [Parliamentarism in Hungary. Parliament, parties, elections] Budapest: Korona.

Gerhard, P. (2010). 'A politika személyessége [Personalness of politics]'. Budapesti Negyed [Budapestian District] 18 (2), pp. 181-209.

Retrieved April 2, 2018 from http://epa.oszk.hu/00000/00003/00052/pdf/.

Gerö, A. (1997). The Hungarian Parliament (1867-1918). A Mirage of Power. New York: Atlantic Research Publications.

Lutter, J. and Hickersberger, M. (2000). Wahlkampagnen aus normativer Sicht [Election campaigns from a normative perspective]. Wien: Universität Wien.

Mihályffy, Zs. (2009). Politikai kommunikáció elméletben és gyakorlatban [Political communication it theory and practice]. Budapest: L'Harmattan.

Nieuwenhuis, I. (2017). 'Performing rebelliousness: Dutch political humor in the 1780s', Humor: International Journal of Humor Research 30 (3), pp. 261-277.

O'Connor, A. (2017). 'The effects of satire: Exploring its impact on political candidate evaluation', in Davis, J. M. (ed.), Satire and Politics: The Interplay of Heritage and Practice. London: Palgrave Macmillan, pp. 193-225.

Plasser, F. (2009). 'Political consulting worldwide', in Johnson, D. W. (ed.), Routledge Handbook of Political Management. New York: Routledge, pp. 24-41. Retrieved April 2, 2018 from

file://C:/Users/Tam\%C3\%A1s\%20\%C3\%81gnes/Downloads/RoutledgeHandbooks9780203892138-chapter3.pdf.

Sanz, M. J. P. (2013). 'Relevance theory and political advertising. A case study'. European Journal of Humour Research 1 (2), pp. 10-23. Retrieved April 2, 2018 from https://europeanjournalofhumour.org/index.php/ejhr/article/view/Pinar\%20Sanz.

Sipos, B. (2011). Sajtó és hatalom a Horthy-korszakban: politika-és társadalomtörténeti vázlat [Press and power in the Horthy Era: A political and social historical sketch]. Budapest: Argumentum.

Strömbäck, J. \& Kiousis, S. (2014). 'Strategic political communication in election campaigns', in Reinemann, C. (Hrsg.), Political Communication, Berlin: De Gruyter Mouton, pp. 109128. Retrieved April 2, 2018 from

https://www.researchgate.net/publication/263353301_Strategic_Political_Communication in Election Campaigns.

Tamás, Á. (2010). 'Serbs, Croatians and Romanians from Hungarian and Austrian perspectives: Analysis of caricatures from Hungarian and Austrian comic papers', in Demski, D. and Baraniecka-Olszewska, K. (eds.), Images of the Other in Ethnic Caricatures of Central and Eastern Europe, Warsaw: Polish Academy of Sciences, pp. 272-297.

Tamás, Á. (2014). Nemzetiségek görbe tükörben. 19. századi nemzetiségi sztereotípiák Magyarországon [National groups in twisted mirror. National stereotypes in Hungary in the 19th century]. Pozsony: Kalligram.

Toth, A. (1973). Parteien und Reichstagswahlen in Ungarn, 1848-1892 [Parties and parliamentary elections in Hungary, 1848-1892]. München: Oldenbourg Verlag.

Tsakona, V. (2013). 'Parliamentary punning: Is the opposition more humorous than the ruling party?' European Journal of Humour Research 1 (2), pp. 101-111. Retrieved April 2, 2018 from https://europeanjournalofhumour.org/index.php/ejhr/article/view/Tsakona. 